\title{
On Political Morality and the Conditions for Warranted Self-Respect
}

\author{
Matthew H. Kramer ${ }^{1}$
}

Received: 7 August 2017/Accepted: 8 August 2017/Published online: 21 August 2017

(C) The Author(s) 2017. This article is an open access publication

\begin{abstract}
In my recent book Liberalism with Excellence (2017: chapter 7), I have expounded at length a conception of warranted self-respect. That conception, which draws heavily though far from uncritically on the scattered passages about selfrespect in the writings of John Rawls, is central to my defense of a variety of liberalism that combines and transfigures certain aspects of Rawlsianism and perfectionism. However, it is also central to the positions taken in some earlier books of mine on capital punishment and torture. (Kramer, The ethics of capital punishment, Oxford University Press, Oxford, 2011; Torture and moral integrity, Oxford University Press, Oxford, 2014) Although my understanding of warranted selfrespect was presented far more briefly or obliquely in each of those earlier books than in Liberalism with Excellence, it in fact underlies both my limited defense of the death penalty and my absolutist insistence that the use of interrogational torture is never morally permissible. The present paper will recount the gist of my conception of warranted self-respect and will then explain how that conception figures pivotally in my ruminations on the diverse matters of political morality that have been mentioned here.
\end{abstract}

Keywords Capital punishment $\cdot$ Death penalty $\cdot$ Liberalism $\cdot$ Perfectionism $\cdot$ John Rawls · Self-respect · Stoicism · Torture

In my recent book Liberalism with Excellence (2017: chapter 7), I have expounded at length a conception of warranted self-respect. That conception, which draws heavily though far from uncritically on the scattered passages about self-respect in the writings of John Rawls, is central to my defense of a variety of liberalism that combines and transfigures certain aspects of Rawlsianism and perfectionism.

Matthew H. Kramer

mhk11@cam.ac.uk

1 Churchill College, Cambridge University, Cambridge CB3 0DS, England, UK 
However, it is also central to the positions taken in some earlier books of mine on capital punishment and torture. (Kramer, The ethics of capital punishment, Oxford University Press, Oxford, 2011; Torture and moral integrity, Oxford University Press, Oxford, 2014) Although my understanding of warranted self-respect was presented far more briefly or obliquely in each of those earlier books than in Liberalism with Excellence, it in fact underlies both my limited defense of the death penalty and my absolutist insistence that the use of interrogational torture is never morally permissible. The present paper will recount the gist of my conception of warranted self-respect and will then explain how that conception figures pivotally in my ruminations on the diverse matters of political morality that have been mentioned here.

\section{Warranted Self-Respect as Warranted Self-Esteem}

Let us begin with a famous passage from John Rawls's A Theory of Justice (1971: 440):

We may define self-respect (or self-esteem) as having two aspects. First of all,...it includes a person's sense of his own value, his secure conviction that his conception of his good, his plan of life, is worth carrying out. And second, self-respect implies a confidence in one's ability, so far as it is within one's power, to fulfill one's intentions. When we feel that our plans are of little value, we cannot pursue them with pleasure or take delight in their execution. Nor plagued by failure and self-doubt can we continue in our endeavors. It is clear then why self-respect is a primary good. Without it nothing may seem worth doing, or if some things have value for us, we lack the will to strive for them.

Although this passage is in need of some modifications and qualifications and amplifications, it elegantly conveys several of the key elements in my own account of warranted self-respect. Rawls was correct in declaring that self-respect is best understood as self-esteem which comprises both self-worth (a sense that one's projects and objectives are valuable) and self-confidence (a sense that one will be able to do many of the things which one sets out to do).

Rawls has been criticized by some commentators for running together the notion of self-respect with the supposedly distinct notion of self-esteem. Such commentators usually hold that self-respect consists in a sense of oneself as an agent who should always be treated as an end and never solely as a means, whereas self-esteem consists in a favorable appraisal of one's own accomplishments or talents or projects or attractiveness or personality or relationships. Those critics maintain that the paramount primary good that should have been identified by Rawls as such is selfrespect in the Kantian sense just indicated, rather than self-esteem. However, as I have argued at length in Liberalism with Excellence (2017: 300-322), any objections to Rawls along these lines are inapposite-partly because self-respect in the Kantian sense is always a component of self-esteem, and partly because self- 
esteem is what fully partakes of the features that led Rawls to classify it as a primary good.

Of course, although self-respect as self-esteem (or, rather, warranted self-respect as warranted self-esteem) is a primary good, it is a primary natural good rather than a primary social good. ${ }^{1}$ In other words, it is never a distribuendum directly apportioned by any system of governance. Instead, it is like health or intelligence as a desideratum which should be fostered by a system of governance but which cannot be directly controlled in its distribution by any such system. Governmental functionaries can never ensure that each person in a society will harbor an ample sense of self-respect, nor can they ensure that each person would be warranted in harboring such a sense.

One way in which the quoted remarks by Rawls stand in need of amplification is signaled by what has just been said. Rawls focused on self-respect as a primary good-indeed as the most important of the primary goods-but he should instead have focused on warranted self-respect. Whereas self-respect is fundamentally a psychological property, warranted self-respect is fundamentally ethical as well as psychological. It is the level of self-esteem that is appropriate in response to one's successes and failures and abilities and aspirations and relationships. Although the level of self-respect actually felt by anyone is a subjective property, the warrantedness or unwarrantedness of that level of self-respect is an objective ethical matter. (Note that the unwarrantedness of someone's sense of self-respect can be in the direction either of excess or of deficiency. A person can deludedly overestimate her achievements or other admirable qualities, but alternatively she can assess those achievements and qualities too negatively.)

\section{A Government's Responsibility to Promote Warranted Self-Respect}

Although the preceding section furnishes only the barest sketch of a much longer exposition in my 2017 book, it is sufficient for the purposes of this article. We should now ponder the role of a government in promoting the incidence of warrantedly high levels of self-respect among the people in the society over which the government presides. As has already been indicated, that role does not involve any direct distribution of levels of warranted self-respect. Warranted self-respect is a primary natural good rather than a primary social good. Instead of treating it as a distribuendum, a system of governance is morally obligated to bring about the political and socioeconomic conditions under which every member of a society can be warranted in feeling an ample sense of self-respect.

Of course, as has been stated, no system of governance can ensure that every member of a society will indeed harbor an ample sense of self-respect; nor can any such system ensure that every member will be warranted in harboring such a sense. Like the level of health enjoyed by any particular individual, the level of selfrespect experienced by her is determined by numerous contingencies of her

\footnotetext{
1 On the distinction between primary social goods and primary natural goods, see Rawls (1971: 62). See also Kramer (2017: 325-328).
} 
biography and temperament. Similarly, the level of self-respect that would be warranted for any particular individual is determined by numerous contingencies of her biography and abilities as well as by socioeconomic and political conditions. (My references here to a person's biography naturally encompass her relationships with other people.) Because the quantum of actual self-respect and the quantum of warranted self-respect for each person are so heavily dependent on the peculiarities of her circumstances, no system of governance is morally obligated to bring about a situation where everyone is warranted in harboring an ample degree of self-respect which he or she actually harbors. Such a situation can fail to obtain-indeed, it will scarcely ever obtain-even if a system of governance has fulfilled all its responsibilities.

What a system of governance is morally obligated to do, however, is to bring about the socioeconomic and political conditions under which every member of a society can be warranted in feeling a solid sense of self-respect. Dependent though levels of warranted self-respect are on the particularities of individuals' lives, they are also determined crucially by the general socioeconomic and political arrangements over which a government can exert substantial influence. Rawls explored in depth the connections between such arrangements and the incidence of the primary good of self-respect; the aspirational perfectionism which I defend in Liberalism with Excellence concentrates even more wide-rangingly on those connections. Appropriate socioeconomic and political institutions are not alone sufficient to enable every person to be warranted in sustaining a high level of self-respect, but for any ordinary person they are a necessary condition for being so warranted. Thus, every system of governance is morally obligated to develop and uphold such institutions. I will henceforth use the phrase "foremost responsibility" to refer to this moral obligation which is incumbent on every system of governance.

\section{Aspirational Perfectionism Versus Edificatory Perfectionism}

Although the influence of socioeconomic and political arrangements on people's warranted levels of self-respect is multifaceted, Liberalism with Excellence chiefly addresses two main forms of that influence. The book's first engagement with the matter occurs in its confrontation with edificatory perfectionism. Edificatory perfectionism comprises a diverse array of theories whose proponents maintain that-at least in principle-governments are sometimes morally permitted and morally obligated to steer people toward ways of life that are more flourishing or upright or wholesome or successful or robustly autonomous. According to such philosophers, governments are morally permitted and morally obligated to undertake arrangements that will induce people to edify themselves by developing and exerting their capacities. Liberalism with Excellence contends that, insofar as a society's political institutions act for the purpose of edifying individuals rather than for the purpose of preventing injustices or fostering prosperity and public order and other public goods, those institutions will not be supportive of warrantedly high levels of self-respect (chapter 6). Such an effect will be especially pronounced if the governmental actions involve coercion or manipulation, but it will occur even if 
those actions consist solely in positive enticements such as subsidies or tax exemptions. For two main reasons, the adoption of any such measures for the purpose of edifying the citizenry is contrary to a government's foremost responsibility. Those measures tarnish the relationship between citizens and governmental functionaries, for they are based on officiously derogatory judgments akin to those that animate the meddlesomeness of a busybody; and they demean the system of governance by tying the success of its operations partly to matters that would be beneath its notice if it concerned itself not with citizens' harmless foibles but with its own foremost responsibility.

The effects of edificatory policies are scarcely the only nexus between socioeconomic or political conditions and the warranted levels of self-respect of individuals. In addition, my alternative variety of perfectionism-aspirational perfectionism - is centered on the ways in which the excellence of a society bolsters the levels of self-respect that individuals are warranted in sustaining. People very often do take pride in the accomplishments of their contemporaries and predecessors as well as in their own accomplishments, and they are frequently warranted in doing so. Vicarious pride is frequently warranted because the life of virtually every individual unfolds in networks of relationships that bear importantly on how well that life has gone. ${ }^{2}$ Given that such pride is frequently warranted, the foremost responsibility of a government will include a responsibility to foster the occurrence of outstanding achievements. Those outstanding achievements help to endow with excellence the society over which a government presides, and they thereby contribute to the government's fulfillment of its foremost responsibility-since the members of the society can warrantedly feel better about themselves by dint of warrantedly feeling better about their status as such members. Conversely, the members of a meanly unaccomplished society can be warranted in feeling worse about themselves inasmuch as they are warranted in feeling abashed about their status as such members.

Of course, the foregoing two paragraphs provide no more than an extremely skimpy outline of aspirational perfectionism. The assertions in those paragraphs have not been supported here by any relevant argumentation. However, because I have presented the relevant argumentation at length in Liberalism with Excellence, and because my purpose here is simply to sketch how the foremost responsibility of any system of governance is central to aspirational perfectionism, the remarks in the foregoing two paragraphs are sufficient.

Before we turn to the death penalty and to torture, however, one caveat should be entered. Although the cultivation of sterling accomplishments in areas such as art and literature and science and athletics can be crucial for the fulfillment of a government's foremost responsibility, the securing of people's basic rights and liberties is even more important as a measure by which a government satisfies that responsibility. If the securing of people's basic rights and liberties is itself understood as a mode of excellence — as Rawls took it to be in A Theory of Justice,

\footnotetext{
${ }^{2}$ As should be evident, the notion of how well a life goes is understood here in what Derek Parfit termed an "objective-list" sense. (Parfit 1984: 499) Such an understanding is singularly appropriate in ruminations on the objective warrantedness of levels of self-respect.
} 
and as I take it to be in Liberalism with Excellence-it is the paramount aspirational-perfectionist objective which any system of governance is morally obligated to realize. If aspirational perfectionism is instead construed more narrowly to comprehend all modes of excellence except for the securing of people's basic rights and liberties, then aspirational-perfectionist policies are subordinate to the policies whereby those rights and liberties are protected. Whatever position anybody adopts on that matter of taxonomy, ${ }^{3}$ the key point is that the upholding of basic rights and liberties and the fostering of other modes of excellence are the means by which a system of governance meets its foremost responsibility. Albeit the nurturance of outstanding feats in areas such as art and literature and science and athletics is always lexically posterior to the effectuation of the basic rights and liberties of individuals, it too is generally constitutive of the conditions under which each individual can be warranted in sustaining an ample quantum of self-respect.

\section{The Purgative Rationale for the Death Penalty}

Though most of the chapters in my book The Ethics of Capital Punishment (2011) are devoted to assailing all the standard rationales for the death penalty, the penultimate chapter of the book expounds an alternative rationale that applies in a very limited range of cases. Biblical in origin but strictly secular in my exposition, the purgative rationale maintains that the life of someone who perpetrates extravagantly evil crimes is ethically dominated by those crimes and is therefore an affront to humanity. The continued existence of someone who has committed such atrocities will defile the moral character of the society in which he or she abides. Though the officials who govern that society may not have been complicit in the perpetration of those atrocities, they become and remain complicit in the continuation of the life of the perpetrator-insofar as they have gained control over him or should have gained control over him. By failing or refusing to execute such a person after fair legal proceedings (including opportunities for appeals), a system of governance becomes defiled. That defilement impairs a government's compliance with its foremost responsibility.

Although the assertions in the preceding paragraph have merely gestured toward the complex arguments that underlie the purgative rationale, and although those assertions have not addressed any of the objections which I ponder in my 2011 book and in a subsequent article (Kramer 2015), my concern here is simply to expand somewhat on the point stated in the final sentence of that paragraph. Why would the continuation of the life of a defilingly evil wrongdoer impede the realization of the

\footnotetext{
3 It is a taxonomical matter rather than a substantive matter because it does not concern any of the following questions, each of which is to be answered affirmatively: (1) whether the effectuation of individuals' basic rights and liberties is a morally obligatory and vital endeavor for every system of governance; (2) whether the fostering of excellent accomplishments in areas such as the arts and sciences is typically a morally obligatory endeavor for a system of governance; (3) whether the principle of justice that makes the former endeavor obligatory is lexically prior to the principle of justice that makes the latter endeavor obligatory. Instead, the sole matter at issue-a taxonomical matter-is whether aspirational perfectionism encompasses only the latter endeavor or also the former endeavor.
} 
political and socioeconomic conditions under which everyone in a society can be warranted in feeling an ample sense of self-respect? Let us mull over an analogy. ${ }^{4}$

Suppose that Mary has been horrifically persecuted by John. He has brutally tortured and decapitated her husband and children, and he has repeatedly raped and tortured her while keeping her chained for months to the wall of an appalling dungeon. When he is eventually apprehended, he shows no contrition whatsoever; like Aaron in Shakespeare's Titus Andronicus, he regrets only that he has been captured and that he therefore cannot commit further atrocities. Not long after his arrest, he becomes seriously ill. The lone course of action that can save his life is a transfusion of blood, and the sole person in the region with blood of a type that will be accepted by John's body is Mary. Patently, Mary is not under a moral obligation to donate any blood to sustain the life of John. More interesting is the question whether she is under an ethical obligation to decline to sustain his life. The answer to that latter question is affirmative. In the circumstances just outlined, where John has subjected Mary and her husband and children to a string of gruesome outrages and has undergone no remorse, she would debase herself if she were to take any steps to prolong his life. An ethic of ostensible magnanimity in these extreme circumstances would be an ethic of self-contempt.

Admittedly, the analogy in the preceding paragraph has to be handled with caution. Mary's situation differs in some significant respects from the situation of the officials in a system of criminal justice who have to determine how a monstrous offender such as John is to be punished. Nevertheless, because the chief differences cut in contrary directions, the analogy proves to be quite serviceable.

On the one hand, if Mary declines to donate any blood, she has not killed John through an active endeavor. Rather, she has let him die. In that regard, her course of conduct is not akin to the steps taken by legal officials when they execute a capital offender. Under any credible reckoning, those steps by the officials are actions rather than omissions. Now, for reasons that can be gathered from my discussions of the act/omission dichotomy elsewhere 5 - discussions to which I shall return in my remarks on interrogational torture later in this article-any ethical considerations sufficient to underlie an obligation-to-terminate-somebody's-life-through-an-omission might not be sufficient to underlie an obligation-to-terminate-somebody's-lifethrough-an-action. Ceteris paribus, the considerations that minimally suffice to underlie the existence of an obligation of the latter kind are weightier than those that minimally suffice to underlie the existence of an obligation of the former kind. Consequently, this first main dissimilarity between Mary's situation and the situation of the criminal-justice officials is a factor that calls for wariness. When we start with a premise about her being under an obligation to forbear from preserving John's life, we are well advised to be cautious about inferring therefrom that the officials are under obligations to execute monstrous offenders such as John.

On the other hand, Mary is a private individual who has been directly victimized by John's dreadful crimes. If she declines to donate any blood to save John's life,

\footnotetext{
4 This analogy is borrowed-with some important modifications-from Kramer (2015: 387-388).

5 See especially Kramer (2014: 77-97, 193-196, 202). My discussions there draw quite heavily at times on my earlier exposition of the act/omission dichotomy in Kramer (2003: 324-335).
} 
moreover, she will not have reached her decision in order to defend herself or anyone else against his onslaughts; his onslaughts have already been halted. An active endeavor by her to terminate his life or to immure him as a prisoner, outside any contexts in which she is defending herself or others against imminent dangers, would be unlawful and morally illegitimate (though of course understandable). Any such endeavor, outside such contexts, would consist in the pursuit of vengeance rather than in the pursuit of justice. Officials in a system of criminal law, by contrast, are positioned to pursue justice from an impartial perspective. They act on behalf of their community, and in extreme cases on behalf of humankind. They can legitimately undertake punitive measures that would not be legitimate if undertaken by Mary or by any other private individual acting in a private capacity. The range of punishments which they can legitimately impose is far from unlimited, of course, but it includes a number of active punitive endeavors.

In short, because these two principal dissimilarities between Mary's decision and a sentencing decision by a criminal-justice official cut in opposite directions, my scenario of Mary and John can well serve the purpose for which I have adduced it. That is, it presents an extreme situation in which a person's choosing to extend somebody else's life would move the person away from the conditions under which she can be warranted in harboring an ample sense of self-respect. It would amount to a form of self-abasement and thus to a wrong against herself. If the officials in a system of criminal justice balk at the execution of a monstrous offender and decide that instead resources should be devoted to prolonging his life, ${ }^{6}$ they likewise detract from the conditions under which every member of their society can be warranted in feeling an ample sense of self-respect. Whereas Mary through the donation of blood to John will have breached a duty of elementary respect which she owes to herself, the officials through a decision against an execution (after fair legal proceedings) will have breached a duty which they owe to members of the public at large. In an extreme case where a defendant has committed a medley of loathsome atrocities that render his life an affront to humankind, a judgment with the effect of allocating resources to the continuation of his life is a course of action that hinders the efforts of a government to fulfill its foremost responsibility.

Naturally, my connecting of the purgative rationale for capital punishment to the foremost responsibility of any system of governance will not be of great interest unless the purgative rationale is sound. In the present article, I have laconically summarized that rationale instead of propounding arguments in support of it (though the analogy involving John and Mary, notwithstanding its imperfections, does supply a wee bit of support). However, the task of sustaining the purgative rationale with suitable lines of argumentation is precisely what I have pursued in The Ethics of Capital Punishment. Here the much more limited task has been to show how that rationale fits together nicely with the positions taken in some of my recent books on quite different topics. What unifies my approaches to those topics is their shared grounding in the foremost responsibility of every system of governance.

\footnotetext{
${ }^{6}$ Of course, the officials will have decided to punish him through some alternative sanction such as lifelong incarceration or banishment. However, a corollary of punishing him in some alternative fashion is that resources will be devoted to continuing his life. This point applies even if the funding for those resources can be obtained through the seizure of assets that belong to the offender.
} 


\section{Torture and Warranted Self-Respect}

In Torture and Moral Integrity (2014), I have maintained that interrogational torture and other familiar modes of torture are always and everywhere morally wrong. That is, any instance of such torture is in contravention of a moral prohibition to which there are no exceptions. To be sure, in some formidably rare circumstances the duty contravened by an instance of torture might be less stringent than a countervailing duty to proceed therewith in order to avert a calamity. Still, the reason why any such situation would consist in a moral conflict - a conflict between a duty to $\varphi$ and a simultaneous duty not to $\varphi$-is that neither of the clashing duties in the conflict is canceled or suspended by the clash. Each of them continues to exist as a moral duty. Consequently, even in the extreme circumstances where the perpetration of interrogational torture would be less gravely wrong than the remissness of declining to perpetrate it, it would be a serious wrong. Its wrongness would be extenuated, but not eliminated, by the exigency of the circumstances.

To discern how my absolutist position on the use of interrogational torture is connected to my focus on a government's foremost responsibility, we need to consider briefly why the use of such torture is always and everywhere wrong. Because my 2014 book distinguishes among many different types of torture, and because the details of my reflections on the wrongness of torture vary across those different types, we should also briefly probe the wrongness of another type of torture: punitive torture. We can thereby see that the absolute wrongness of punitive torture, like the absolute wrongness of interrogational torture, is integrally linked to the foremost responsibility of every system of governance. Though the specifics of the factors that account for the wrongness of torture are somewhat different across the distinct kinds of torture, the wrongness in each case pertains directly to the impairment of the political and socioeconomic conditions under which every member of a society can be warranted in harboring a hearty sense of self-respect.

\subsection{Interrogational Torture}

A full account of the wrongness of interrogational torture would require a separate article. Within the highly limited compass of this subsection, the easiest way to approach the matter of the wrongness of such torture is to draw a contrast with a quite different type of torture. Although nearly all kinds of torture are always and everywhere morally wrong, two kinds can be morally permissible in some extreme circumstances. Most notable for my present purposes is that some possible instances of ephemerally incapacitative torture are morally permissible. (Kramer 2014: 186-187; 2017: 260-261) The phrase "ephemerally incapacitative torture" refers here to the deliberate affliction of a malefactor with severe pain for the purpose of inducing him to desist from his ongoing performance of a very seriously wrongful action, where the harmful effects of the torture are neither intended to last permanently nor likely to last permanently. If the infliction of the severe pain is the least harmful means that is feasible as a way of preventing the completion of the seriously wrongful action, it can be morally legitimate. 
Consider, for example, the following scenario which recounts a variant of a situation broached initially by Uwe Steinhoff and discussed at some length by me in my book on torture. (Kramer 2014: 87-88; Steinhoff 2009: 44) When a rapist assails a young woman and begins to tear her clothes off, she manages to stomp on his foot with one of her stiletto heels three or four times in order to afflict him with exquisite pain. Her hope is that the searingness of the pain will induce him to desist from his act of rape, as he loses his ability to concentrate on his ravishing of her and is instead absorbed by the consumingness of his own agony. He does indeed involuntarily cease to clutch her, and she escapes from her plight while he writhes in anguish. Her wielding of ephemerally incapacitative torture has been unequivocally permissible in the circumstances.

Now, if we train our attention solely on the interests of the victim of the ephemerally incapacitative torture, we shall be unable to explain why the young woman's act is morally permissible whereas no act of interrogational torture is ever morally permissible. ${ }^{7}$ After all, even though the harmful effects of her stomping on the rapist's foot are neither intended to persist permanently nor likely to persist permanently, those effects-which might include some broken bones or other significant injuries as well as the agony-are undoubtedly more severe than the harmful effects of some instances of interrogational torture. Thus, if we analyze the situation from a victim-focused perspective that concentrates on the interests of a tortured person in being free from excruciating pain and injuries, we will not be able to fathom the following combination of facts: (1) the fact that the young woman's repelling of her attacker through the deliberate infliction of severe pain is morally permissible, and (2) the fact that the deliberate infliction of severe pain for the purpose of extracting information that can help to avert some calamity is never morally permissible. The combination of those two facts will be baffling from a victim-focused perspective, since some instances of calamity-averting interrogational torture foreseeably cause less damage to the interests of their victims than the damage foreseeably caused by the young woman's use of ephemerally incapacitative torture.

Consequently, to grasp why the wrongness of interrogational torture is absolute whereas the wrongness of ephemerally incapacitative torture is not, we need to shift to a viewpoint focused on the moral probity of the perpetrator. When we switch to such a viewpoint, we can see that a pivotal matter for differentiating between the morality of interrogational torture and the morality of ephemerally incapacitative torture is the act/omission distinction. While torture of the former kind is aimed at inducing an information-imparting action, torture of the latter kind is aimed at inducing an omission by thwarting a seriously wrongful action. Given as much, and given the demarcation of the act/omission dichotomy-which is expounded rigorously and sustainedly in my book on torture (2014: 77-97, 193-196)—-torture

\footnotetext{
7 To forestall any misunderstandings, I should note that the victim of the ephemerally incapacitative torture is the perpetrator of the crime of rape whereas the perpetrator of the torture is the victim of the crime of rape. Because my distinction here between a victim-focused perspective and a perpetratorfocused perspective is drawn in relation to the torture rather than in relation to the rape, the person relevantly classifiable as the perpetrator is the young woman while the person relevantly classifiable as the victim is her assailant.
} 
of the former kind is far more minutely controlling, with far more fine-grained direction of the victim's behavior, than is torture of the latter kind. Hence, the outlook associated with the perpetration of torture of the former kind is always overweening in ways in which the outlook associated with the perpetration of torture of the latter kind is not. Some instances of ephemerally incapacitative torture are consistent with an ethic of self-restraint, whereas every instance of interrogational torture is not.

Of course, the preceding paragraph does no more than to supply a précis of one of the relevant lines of argument in my 2014 book, instead of elaborating any fullblown argumentation here. However, the specifics of that lengthy line of reasoning-and in particular the complexities of drawing the act/omission distinction rigorously - are well beyond the scope of the present paper. My point at the moment is simply to underscore the significance of a shift from a victimfocused perspective to a perpetrator-focused perspective. Only from that latter perspective, with its concentration on the moral integrity of the perpetrator(s) of torture, does the morally decisive difference between interrogational torture and ephemerally incapacitative torture become visible. Torture of either type can set back the interests of victims as much as torture of the other type, but the perpetration of interrogational torture involves extravagantly god-like controllingness that is not similarly characteristic of the perpetration of ephemerally incapacitative torture. That perpetrator-focused divergence between those two kinds of torture, which a purely victim-focused perspective neglects, is the key to the absolute wrongness of interrogational torture and the variability of the moral status of ephemerally incapacitative torture.

If an instance of interrogational torture is performed by anyone who is acting on behalf of a system of governance (as an official or as a private contractor, for example), it detracts from the political conditions under which every member of a society can be warranted in harboring a solid sense of self-respect. Its impairment of those conditions is similar in a key respect to the impairment of those conditions by edificatory-perfectionist policies. In each case, some measures undertaken by a government's officials or by others acting on its behalf are so overweening as to counter its fulfillment of its foremost responsibility. To the extent that a system of governance forgoes the self-restraint that befits its relationship with members of the public, it moves away from discharging its foremost responsibility.

Of course, notwithstanding the major affinity just highlighted, there are some notable dissimilarities between the wrongness of interrogational torture and the wrongness of edificatory-perfectionist policies. If an instance of interrogational torture is performed in the absence of a dreadful emergency that extenuates the immorality of its occurrence, the gravity of the wrongness of such torture will far exceed the gravity of the wrongness of any edificatory-perfectionist policy that is likely to be adopted in a modern liberal democracy. Even in the presence of a dire emergency, the perpetration of interrogational torture will typically be a considerably graver wrong than will any credible edificatory-perfectionist endeavors. Still, despite that obvious disparity and some further divergences, my focus on the foremost responsibility of any system of governance is conducive to our discerning 
a deep point of homology between the wrongness of interrogational torture and the wrongness of edificatory perfectionism.

\subsection{Punitive Torture}

Although punitive torture shares most of the conspicuous features of interrogational torture-not least the deliberate infliction of severe pain-it is undertaken for a different purpose. Instead of using severe pain as a means of extracting information, a perpetrator of punitive torture uses it as a means of disciplining a person who is thought to have committed some serious misdeeds. (Of course, although those purposes are distinct, they are combinable.) The wrongness of punitive torture is flagrant in circumstances where no harsh sanction at all is appropriate, but such torture is wrong even in circumstances where an extravagantly evil malefactor deserves to undergo it. We should mull over a situation of the latter sort, in order to apprehend why punitive torture is always and everywhere wrong.

Suppose that Josef Mengele-directly responsible for hundreds of thousands of deaths and gruesome atrocities at Auschwitz-had been captured and brought to justice after the Second World War instead of being sheltered by Argentina and Paraguay and Brazil. Given that Mengele had perpetrated thousands of acts of grisly torture, the subjection of him to punitive torture would have been richly deserved. Nonetheless, he had a moral right not to be subjected to such torture. That right was justificatorily traceable not to the importance of his interest in being free from excruciating pain - an interest that was of no positive ethical weight whatsoeverbut instead to the importance of upholding the moral integrity of any system of governance whose officials had managed to arrest and convict him. By stooping to afflict Mengele with the torture which he thoroughly deserved, the officials in that system of governance would have degraded its moral integrity and their own moral integrity by using the system's punitive mechanisms to cater to urges for revenge. Though Mengele could legitimately have been executed and should have been executed, the subjection of him to torture would have turned the process of punishment into an enterprise of vindictive self-indulgence. He deserved no better; still, had a system of governance eschewed all normal restraints for the purpose of giving him torturously what he deserved, it would have debased itself by vengefully effecting a qualitative correspondence between its punitive responses and some of his iniquities. However understandable and primally satisfying such responses would have been, they would have overstepped the bounds within which a system of governance must remain if it is to differentiate its own workings from the gross unrestraint to which its punitive measures are addressed. Thus, Mengele had a moral right not to be subjected to punitive torture, even though his interest in being free from excruciating pain did not contribute at all to the justification for his having such a right. Justificatorily, that right was entirely derivative of the moral duties borne by the officials who might have captured Mengele. Its justification lay in the furtherance of their moral probity rather than in the furtherance of his well-being. ${ }^{8}$

\footnotetext{
${ }^{8}$ For more detailed argumentation-perpetrator-focused argumentation-about the moral illegitimacy of punitive torture, see Kramer (2014: 203-209).
} 
In presenting a general combination of self-aggrandizement and self-abasement, the wrongness of punitive torture is parallel to the wrongness of edificatory perfectionism and the wrongness of interrogational torture. On the one hand, the perpetration of torture as a mode of punishment exceeds the proper bounds of government in the way that has just been touched upon. On the other hand, the selfaggrandizement of such a course of action for any system of governance is also selfabasing as a manifestation of ethical weakness. A system of governance healthy enough to abide by an ethic of self-restraint would operate its punitive mechanisms without inclining its citizens and officials to derive gratification from the agony of other people. Given that the derivation of gratification from the extreme anguish of other people is a form of sadism, a system of governance that caters to such an impulse is acting ignominiously.

Insofar as a system of governance does exhibit this pattern of simultaneous selfaggrandizement and self-abasement by stooping to the perpetration of punitive torture, it undermines the political conditions under which every member of its society can be warranted in harboring a firm sense of self-respect. Notwithstanding that many members of the society may derive gratification from the wielding of torture against someone as hideously evil as Mengele, the experiencing of that gratification by anybody will have lowered the level of self-respect which she is warranted in feeling. After all, as I have argued at greater length elsewhere (2017: 286-288), one's derivation of pleasure from the agony of somebody else is both overweening and degrading. It is overweening because it is grounded on the proposition that the excruciating pain of someone else can fitly be enjoyed as a plaything for one's amusement. To adopt such an attitude is to emulate the cruelty of a malignant deity and is thus to act at odds with the fundamental equality between oneself and other mortals who are prone to feelings of anguish. At the same time, one's derivation of pleasure from the agony of someone else is demeaning because it indicates that one's own strengths and sustenance and successes-including one's triumphs over foes-are insufficient for one's contentment, which consequently has to be bolstered through one's awareness of the extreme suffering with which somebody else has been afflicted. Pro tanto, one's outlook is marked by inadequacy. (Note that I am not here propounding an empirical conjecture. Specifically, I am not surmising that everyone inclined to experience gratification from the perpetration of punitive torture against a monstrous evildoer is lacking in self-esteem as a property that can be gauged through psychological testing of some kind. Though such an empirical hypothesis may well be correct, my observation here is conceptual rather than empirical. My point is that nobody would be favorably disposed toward punitive torture as a source of gratification if the contentment derived by him from his strengths and sustenance and successes left him in no need of further gratification.)

Thus, far from bolstering the level of self-respect that each member of a society is warranted in harboring, the perpetration of punitive torture by a system of governance lowers that level. Because the use of such torture bespeaks both the presumptuousness and the degradedness of the system of governance that has not refrained therefrom, it is contrary to the system's foremost responsibility. It runs athwart the political conditions under which everyone can be warranted in cleaving 
to an ample sense of self-respect. In that regard-though obviously not in a number of other ways-punitive torture resembles edificatory perfectionism.

\section{Conclusion}

This paper has not sought to advance arguments which establish that edificatory perfectionism, interrogational torture, punitive torture, and the preservation of the lives of extravagantly evil offenders are morally wrong in ways that detract from a government's fulfillment of its foremost responsibility. Rather, I have merely glanced at the arguments presented in three of my recent books. My purpose here has lain not in re-elaborating those arguments but instead in underlining the connectedness of their disparate foci. Diverse though the topics of the aforementioned books are, my treatment of each topic is situated within a general orientation toward the political conditions under which every member of a society can be warranted in feeling a hearty sense of self-respect.

That orientation can also salutarily inform one's enquiries into other major issues of political morality. In some books to be written during the next several years, I will extend it to debates over freedom of speech, abortion, and general principles of justice. Of course, the fact that those future books of mine will be linked to three of my recent books through their underlying outlook is not due to the availability of some template or algorithm that would extend the outlook mechanically. On the contrary, the substance of the argumentation in each of those future tomes will vary markedly from one tome to the next, just as the lines of reasoning in my book on capital punishment differ strikingly from the lines of reasoning in my book on torture or my book on liberal perfectionism. Nevertheless, what will be common to them is their affirmation that some crucial limits on legitimate governmental action and some crucial reasons for governmental action are located in the foremost responsibility of any system of governance. Diverse though those limits and reasons are in sundry contexts of disputation over matters of political morality, they all stem from the value of warranted self-respect.

What makes that shared orientation so significant is that it comprehends quite a few of the positions in contemporary political philosophy. Its provenance lies in certain Stoical ideas, but my development of it has been influenced even more by Rawls's reflections on self-respect as the most important of the primary goods. While encompassing the Kantian ideal of self-respect that consists in the upholding of one's own status as a deliberative agent, my orientation reaches further-in line with Rawls's reflections-to encompass the aspects of self-worth and selfconfidence that go beyond one's recognition of oneself as an agent. My focus on the warrantedness of self-respect aligns my orientation with one of the central propositions of liberal perfectionism (namely, the proposition that judgments about excellence should inform some exertions of governmental power), as does the way in which I amplify the idea of the social bases of self-respect. Consequently, the outlook distilled in this article not only can form connections among multifarious 
issues of political morality but also can form connections among multifarious schools of thought in political philosophy. ${ }^{9}$

Open Access This article is distributed under the terms of the Creative Commons Attribution 4.0 International License (http://creativecommons.org/licenses/by/4.0/), which permits unrestricted use, distribution, and reproduction in any medium, provided you give appropriate credit to the original author(s) and the source, provide a link to the Creative Commons license, and indicate if changes were made.

\section{References}

Kramer, M. 2003. The quality of freedom. Oxford: Oxford University Press.

Kramer, M. 2011. The ethics of capital punishment. Oxford: Oxford University Press.

Kramer, M. 2014. Torture and moral integrity. Oxford: Oxford University Press.

Kramer, M. 2015. The purgative rationale for the death penalty: Replies to Steiker and Danaher. Criminal Law and Philosophy 9: 379-394.

Kramer, M. 2017. Liberalism with excellence. Oxford: Oxford University Press.

Parfit, D. 1984. Reasons and persons. Oxford: Oxford University Press.

Rawls, J. 1971. A theory of justice. Cambridge: Harvard University Press.

Steinhoff, Uwe. 2009. Justifying defensive torture. In Torture: Moral absolutes and ambiguities, ed. Bev Clucas, Gerry Johnstone, and Tony Ward. Baden-Baden: Nomos.

\footnotetext{
${ }^{9}$ I am very grateful to Angelo Corlett and David Luban for suggesting to me (on separate occasions) that an article on the topic of this paper would be salutary.
} 